\title{
A Radiographic Comparison of Two Methods of Hand and Automated Instrumentation for Preparations of Simulated Curved Root Canals
}

\author{
Comparación Radiográfica de Dos Métodos de Instrumentación Manual y \\ Automatizado para Preparaciones de Canales Radiculares Curvos Simulados
}

Kalena Melo Maranhão \& Ana Cassia Reis²

MARANHÃO, K. M. \& REIS, A. C. A radiographic comparison of two methods of hand and automated instrumentation for preparations of simulated curved root canals. Int. J. Odontostomat., 13(4):493-496, 2019.

\begin{abstract}
The present study evaluated the presence of apical deviation and tapering in preparations performed with the use of the automated handpieces with continuous motion, the K3 Endo system (Group 1) and instrumentation manually with Protaper (Group 2). 30 simulated roots were divided into two groups and prepared according each technique. The alteration caused by root canal preparation was analyzed by radiographs obtained on a radiographic desk fabricated for the study. The results (X2), demonstrated that the K3 Endo produced a smaller incidence of apical deviation and Protaper produced a greater tapering of the root canals.
\end{abstract}

KEY WORDS: root canal preparation, apical deviation, endodontics instruments.

\section{INTRODUCTION}

The preparation of the root canal represents one of the most important phases of endodontic therapy, with the objective of cleaning and disinfecting, besides a suitable final conformation that allows its complete obturation (Schilder, 1974).

However, during instrumentation of the root canals we may have undesirable intercurrences such as deviation of the original channel path, tread formation, zips and perforation. In order to reduce the undesirable effects produced during root canal instrumentation, the endodontic instruments have undergone alterations such as modification in their cross section, penetration guide, taper, increase of diameter and material used for their preparation with the introduction of nickel alloy (Sydney et al., 2001; Amaral et al., 2003; Ferreira et al., 2017).

Several techniques and different types of instruments have been proposed. Among them, are the Rotating System - K3 Endo, which have as characteristics 3 radial surfaces; (Schäfer \& Florek, 2003), which results in a more effective cutting action and variable helical angle, allowing the instrument to push the excised dentin to the coronary portion more efficiently.

More modernly, a new system was inserted into Endodontia, the manual instrumentation performed with Protaper files. The Protaper instruments are manufactured by Dentsply (Fig. 1) and have contiguous variables, straight cross-section cordiform, cutting angle of approximately 60 degrees and do not present radial plane (Schäfer \& Vlassis, 2004; Paqué et al., 2005).

Due to these innovations the objective of this work was to evaluate the occurrence of apical deviation and conicity of the preparation after the rotational instrumentation with the K3 Endo System and manual instrumentation performed with Protaper files.

\footnotetext{
${ }^{1}$ DDS, Mrs, assistent professor, UNINASSAU'S Dental School, Belém, Pará, Brasil.

${ }^{2}$ DDS, Mrs, effective professor, FAMAZ'S Dental School, Belém, Pará, Brasil.
} 


\section{MATERIAL AND METHOD}

Thirty simulated channels were used, with a $30^{\circ}$ gradual curvature. Initially, the working length was determined by inserting a No. $10 \mathrm{~K}$-type file (Maillefer) into the root canals until its tip could be seen in the apical foramen and from this length $1 \mathrm{~mm}$. Prior to this procedure, 8 millimeters were prepared in the initial (cervical) straight portion of each resin block with Gates-Glidden and Largo (Maillefer) drill bits of numbers 1 and 2.

Then, the blocks were randomly divided into two groups of 15 , according to the instrumentation techniques:

Group 1 - Rotational instrumentation: the channels were prepared with the K3 Endo system (SybronEndo), following the manufacturer's instructions. An electric motor model Endo Pro (K Driller), adjusted in the speed of $300 \mathrm{rpm}$ and torque control of $2 \mathrm{~N}$ was used (Fig. 2). Group 2 - Manual Instrumentation: The channels were prepared with Protaper files (Dentsply), following the manufacturer's recommendation.

The artificial channels were fixed on a lathe and prepared by a single operator, previously trained. The files used in the experiment were used one for every 5 samples.

Throughout the instrumentation, the Endo-PTC cream (Formula \& Action) associated to $0.5 \%$ sodium hypochlorite (Formula \& Action) was used and at each instrument change, the irrigation and aspiration of the canal with $5 \mathrm{ml}$ of darkin liquid.
The channels were then filled with radiographic contrast medium Telebrix 30 Meglumina (Guerbet), which was performed with the help of an insulin syringe, aided by a vacuum chamber positioned in the apical region. The standardization of radiographic shots was obtained with the aid of a radiographic platform. In this way, the samples were positioned and radiographed using the X-ray apparatus (Dabi Atlant), with exposure time of 1 second. The process of developing the radiographs was standardized as follows: 1 minute development time, 10 minutes - fixation time and 10 minutes - radiographic wash time.

Sequentially, the radiographs were captured by scanning with the aid of a Sony- $\mathrm{H} 1$ digital camera. Subsequently, the images were transferred to Adobe Photoshop 7.0.1 software. for the visual analysis of the artificial channels, observing the occurrence of apical deviation and the conicity of the preparation.

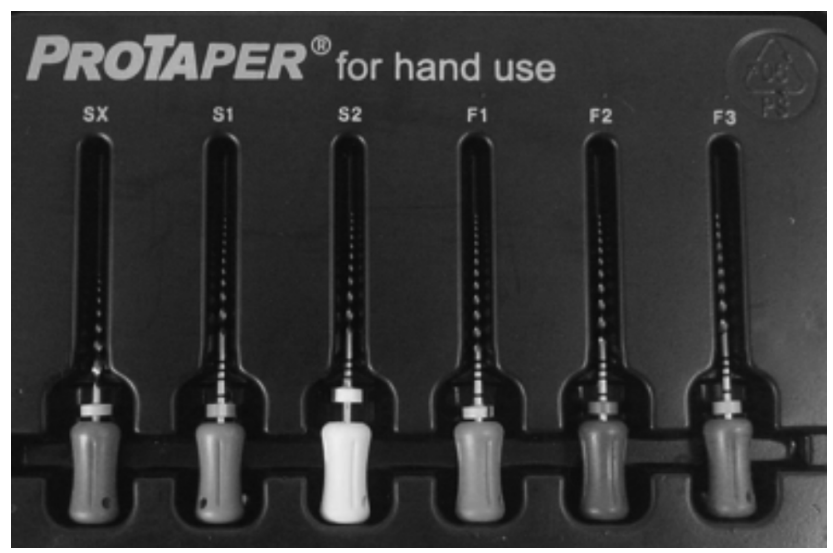

Fig. 1. Protaper files manual (Dentsply).
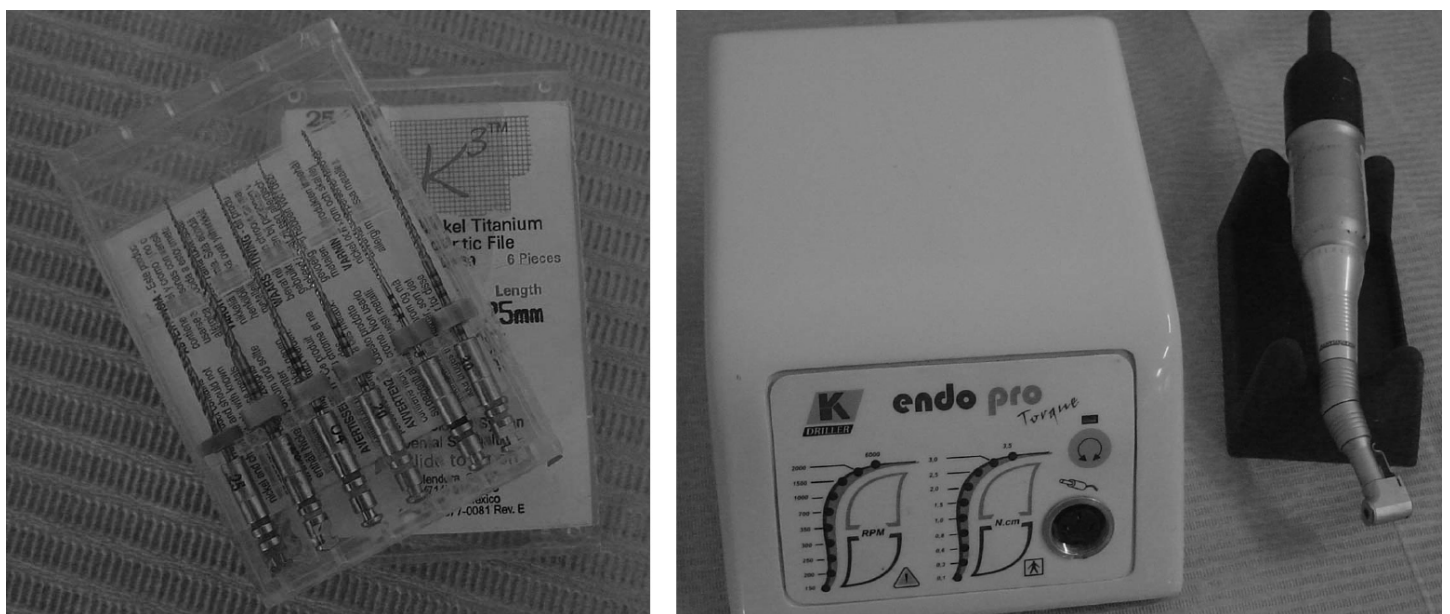

Fig. 2. Files K3 Endo (SybronEndo) and electric motor model Endo Pro (K Driller), adjusted in the speed of $300 \mathrm{rpm}$ and torque control of $2 \mathrm{~N}$. 
The data were then submitted to statistical analysis using the $X^{2}$ test, with a significance level of $5 \%$.

\section{RESULTS}

The results are shown in Tables I and II.

Table I is expressed in numbers and percentages the totals of channels with apical deviation for the two types of files studied.

In Table II is the data referring to the preparation form of the simulated channels, considering the techniques studied.

Table I. Occurrence of apical deviation for the two types of systems studied.

\begin{tabular}{lll}
\hline Apical Deviation & K3 & Protaper \\
\hline Absent & $14(\%)$ & $5(33.3 \%)$ \\
Present & $1(\%)$ & $10(66.7 \%)$ \\
\hline
\end{tabular}

Significant $(p=0,0673)$

Table II. Conical shape provided by the two types of systems studied.

\begin{tabular}{lll}
\hline Conical shape & K3 & Protaper \\
\hline Continuous & $5(33.3 \%)$ & $15(100 \%)$ \\
Discontinuous & $10(66.7 \%)$ & $0(0 \%)$ \\
\hline
\end{tabular}

Significant $(p=0,0005)$

\section{DISCUSSION}

Among the several stages that make up the endodontic treatment, the stage of the chemicalsurgical preparation is emphasized, as a set of measures that aims to obtain complete cleaning and modeling of the root canal system.

A high success rate has been reported in instrumented teeth with manual nickel-titanium files (Amaral et al.; Ferreira et al.). However, the results obtained in this study revealed less occurrence of apical deviation in rotational instrumentation with $\mathrm{K} 3$ Endo files in relation to manual Protaper files (Fig. $3)$.

Another fact is that the Protaper System obtained more continuous preparations (Fig. 3).
These results agree with those obtained by Calberson et al. (2004) and Guelzow et al. (2005).

In both groups, the instrumentation seemed to follow a rather similar course in its beginning. However, it can be observed that the passage of the Protaper S1 to S2 instrument was carried out by requiring a greater effort in order that the curvature was overcome, and the working length reached, leading to a greater time expenditure, due to the realization of recapitulations more frequent, in order to prevent the obstruction of the channels by impaction of debris and operator fatigue, since the amount of structure to be removed should be greater.

Another characteristic differs from the instruments such as the greater flexibility of the K3 Endo files in relation to the Protaper instruments, since the simple manipulation of the instruments proves it, and can be explained by the cordiform cross section, which gives them greater structural mass (Grecca, 2003). However, this characteristic makes it superior, providing more conical preparations.

It should be noted that during the execution of the endodontic preparations, only the fracture of instruments in the technique of manual instrumentation with Protaper files, according to Calberson et al.
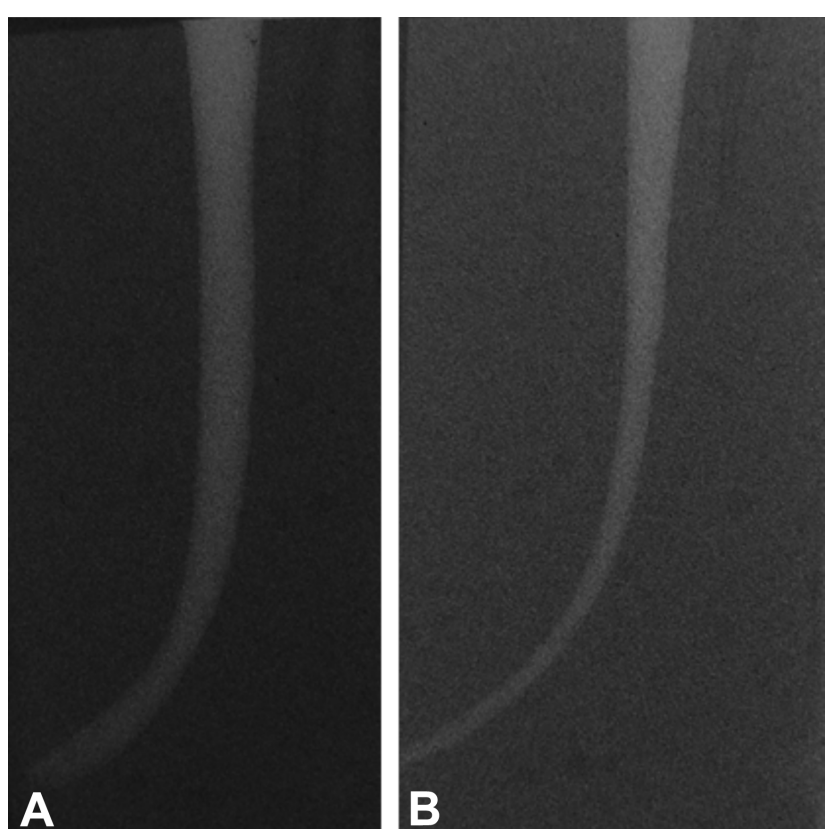

Fig. 3. Panoramic view of the channel after manual instrumentation with Pro-taper (A) and K3 Endo files (B). 


\section{CONCLUSIONS}

In view of the results obtained, it seems reasonable to conclude that:

The K3 Endo files provided a lower apical deviation index when compared to the manual Protaper system.

With respect to the final conical format, Protaper manual files were more satisfactory with respect to K3 Endo files.

MARANHÃO, K. M. \& REIS, A. C. Comparación radiográfica de dos métodos de instrumentación manual y automatizada para preparaciones de canales radiculares curvos simulados. Int. J. Odontostomat., 13(4):493-496, 2019.

RESUMEN: El objetivo de este trabajo fue evaluar la presencia de desviación y conicidad adecuada apical con el uso del sistema de instrumentación de movimiento continuo K3 Endo (Grupo 1) respecto a la instrumentación manual realizada con Limas Protaper (Grupo 2). Treinta canales curvos simulados fueron divididos aleatoriamente en dos grupos e instrumentados por los diferentes sistemas. La alteración causada por la preparación de los canales fue analizada en radiografías obtenidas, en placas ad hoc. Los resultados (X2) demostraron que el K3. Endo produjo una menor incidencia de desviación apical y Protaper produjo una mayor conicidad de los canales radiculares.

PALABRAS CLAVE: preparación de canal radicular, desviación apical, instrumentos endodónticos.

\section{REFERENCES}

Amaral, G.; Lopes, H. P.; Elias, C. N. \& Bombana, A. C. Avaliação da capacidade de corte de limas tipo $\mathrm{K}$ de aço inoxidável e de Níquel-Titânio. J. Bras. Endod., 4(14):223-30, 2003.

Calberson, F. L.; Deroose, C. A.; Hommez, G. M. \& De Moor, R. J. Shaping ability of ProTaper nickel-titanium files in simulated resin root canals. Int. Endod. J., 37(9):613-23, 2004.

Ferreira, F. G.; Barbosa, I. B.; Scelza, P.; Montagnana, M. B.; Russano, D.; Neff, J. \& Scelza, M. Z. Noncontact three-dimensional evaluation of surface alterations and wear in $\mathrm{NiTi}$ endodontic instruments. Braz. Oral Res., 31:e74, 2017.

Grecca, F. S. Avaliação da eficácia dos métodos de instrumentação rotatória (Sistema K3 e Protaper), ultra-som e manual na remoção de corante aderido às paredes de canais radiculares com achatamento proximal. Estudo 'in vitro'. Thesis. São Paulo, Faculdade de Odontologia de Bauru, 2003.

Guelzow, A.; Stamm, O.; Martus, P. \& Kielbassa, A. M. Comparative study of six rotary nickel-titanium systems and hand instrumentation for root canal preparation. Int. Endod. J., 38(10):743-52, 2005.
Paqué, F.; Musch U. \& Hülsmann, M. Comparison of root canal preparation using $\mathrm{RaCe}$ and ProTaper rotary $\mathrm{Ni}$-Ti instruments. Int. Endod. J., 38(1):8-16, 2005.

Schäfer, E. \& Florek, H. Efficiency of rotary nickel-titanium K3 instruments compared with stainless steel hand K-Flexofile. Part 1. Shaping ability in simulated curved canals. Int. Endod. J., 36(3):199-207, 2003.

Schäfer, E. \& Vlassis, M. Comparative investigation of two rotary nickel-titanium instruments: ProTaper versus RaCe. Part 2. Cleaning effectiveness and shaping ability in severely curved root canals of extracted teeth. Int. Endod. J., 37(4):239-48, 2004.

Schilder, H. Cleaning and shaping the root canal. Dent. Clin. North Am., 18(2):269-96, 1974.

Sydney, G. B.; Zamberlan, T. M. A.; Batista, A. \& Mello, L. L. Estudo comparativo da ocorrência de desvio apical com sistemas de rotação alternada. J. B. E., 2:246-52, 2001.

Corresponding author:

Kalena Maranhão

Rus dos Tamios, 1497. Apt. 1001

Batista Campos

CEP: 66025-125

Belém - PA

BRASIL

Email: kalenamaranhao@yahoo.com.br

Recibido : 21-06-2018

Aceptado: 17-09-2018 